\title{
Effect of Grain Moisture Content and Roller Mill Gap Size on Various Physical Properties of Yellow Dent Corn Flour
}

\author{
Muhammad Noor Intan Shafinas ${ }^{1,2}$, Darfour Bernard ${ }^{3}$, Mahmud Nazira $^{4}$ \& Kurt A. Rosentrater ${ }^{5}$ \\ ${ }^{1}$ Faculty of Civil Engineering Technology, Universiti Malaysia Pahang, Lebuhraya Tun Razak, 26300, \\ Kuantan, Malaysia \\ ${ }^{2}$ Center for Sustainable Ecosystem and Natural Resources, Universiti Malaysia Pahang, Lebuhraya Tun \\ Razak, 26300, Kuantan, Malaysia \\ ${ }^{3}$ Radiation Technology Center, Biotechnology and Nuclear Agriculture Research Institute, Ghana Atomic \\ Energy Commission, P.O. Box LG 80, Legon, Ghana \\ ${ }^{4}$ Faculty of Industrial Sciences and Technology, Universiti Malaysia Pahang, Lebuhraya Tun Razak, 26300, \\ Kuantan, Malaysia \\ ${ }^{5}$ Agricultural \& Biosystems Engineering Department, Iowa State University, Elings Hall, Iowa, 50011, \\ Ames, United State \\ Correspondence: Kurt A Rosentrater, Agricultural \& Biosystems Engineering Department, Iowa State \\ University, Elings Hall, Iowa, 50011, Ames, United State. E-mail: karosent@ iastate.edu
}

Received: December 24, $2021 \quad$ Accepted: February 9, 2022 Online Published: February 14, 2022

doi:10.5539/jfr.v11n2p16

URL: https://doi.org/10.5539/jfr.v11n2p16

\begin{abstract}
Corn has six main varieties grown globally for animal feed, human consumption, and commercial/industrial purposes. Flour is an end-product of corn dry-milling. Products that are derived from corn flour often show differences in physical, chemical, and pasting properties due to corn varietal differences, milling methods, differences in flour particle sizes, and drying temperatures. The study aimed to determine the effect of different moisture contents of yellow dent corn and roller gap sizes, on the physical properties of the resulting corn flour. The possibility to use the flour in the manufacturing of animal feed and ethanol production was also considered. Yellow dent corn grain with moisture contents (MC) of $8 \%, 14.0 \%$, and 18\%, and roller gap sizes (GAP) of $0.1016 \mathrm{~mm}, 0.2032 \mathrm{~mm}$, and $0.3048 \mathrm{~mm}$ were used. The Witt corrugated roller mill equipment with rollers of $1 / 32$ inches corrugations was used to produce fine grits and flours. The particle sizes obtained were between 0.54 $\mathrm{mm}$ and $0.75 \mathrm{~mm}$ which increased with an increase in MC and GAP. Grain with $8 \% \mathrm{MC}$ and GAP of $0.1016 \mathrm{~mm}$ and $0.2032 \mathrm{~mm}$, and grain with $14.0 \% \mathrm{MC}$ and GAP of $0.1016 \mathrm{~mm}$ can produce flour of particle sizes good for swine feed. Grain with $8 \% \mathrm{MC}$ and GAP of $0.3048 \mathrm{~mm}$ and grain with $14.0 .0 \% \mathrm{MC}$ and GAP of $0.1016 \mathrm{~mm}$ and $0.2032 \mathrm{~mm}$ can produce flour of particle sizes good for ruminant feed. Grain with $18 \% \mathrm{MC}$ and GAP of 0.1016 $\mathrm{mm}$, and grain with $14.0 \% \mathrm{MC}$ and GAP of $0.2032 \mathrm{~mm}$ can produce flour of particle sizes good for poultry feed. GAP of $0.1016 \mathrm{~mm}$ and $8 \% \mathrm{MC}$ can produce flour of particle sizes suitable for the ethanol production industry. Flour preparation should purposely be done based on grain MC and GAP. The geometric mean diameter of particle sizes ranged from $0.54 \mathrm{~mm}-0.75 \mathrm{~mm}$, and the geometric mean diameter of particle sizes increased with increasing MC and GAP. Also, grains with $8 \% \mathrm{MC}$ had the highest loss in flour, and the higher moisture of $18 \%$ significantly affected the red color of flour.
\end{abstract}

Keywords: roller gap size, moisture content, particle size, yellow dent corn, feed, and ethanol

\section{Introduction}

Globally, corn follows wheat and rice as the third most important cereal crop (Adarkwah, Obeng-Ofori, Büttner, Reichmuth \& Schöller, 2012). Dent corn kernel has corneous, horny endosperm in the sides and back, and has a soft central core. The floury endosperm extends into the crown of the endosperm, it gets collapsed to give a distinct indentation when dried (Johnson, 1991; PE/AI, 2016). Dent corn is the most widely grown corn in the United States Corn Belt, and most parts of the world (Boutard, 2012). Primarily, dent corn is used as animal feed, however, it is also used as a raw material in various industries and can also be used as food (Brown \& Darrah, 1985). 
Dry milling is used to physically change kernels into their constituent endosperms, brans, and germs (Johnson, 1991). Flour is an end-product of corn dry-milling. Food products that are derived from flour show differences in physical, chemical, and pasting properties due to differences in corn varieties (Pan, Eckhoff, Paulsen \& Litchfield, 1996; Nago, Akiossoe, Matencio \& Mestres, 1997; Sandhu, Singh \& Malhi, 2007), methods used in milling (Nghi \& Narasimha, 1994; Martinez-Flores, Martinez, Figueroa \& Gonza-lez, 1998), differences in particle sizes of the flour (Bolade, Adeyemi \& Ogunsua, 2009), and effect of drying temperatures on grains (Hardacre \& Clark, 2006). The benefits of smaller particle sizes are to improve digestion of feed by animals, improve binding ability between particles during pelleting, improve the mixing efficiency of ingredients in a compounded feed, increase particle homogeneity, and prevent ingredient separation (Stark, 2016). Biomass feedstocks flow and compressibility depends mostly on moisture content (MC) and particle size distribution. When MC in bulk powder material is increased, the cohesion and adhesion of particles due to the formation of interparticle bonds get increased (Plinke, Leith, Boundy \& Loffler, 1995; Fitzpatrick, Iqbal, Delaney, Twomey \& Keogh, 2004), and flowability of the feed processing decreases (Yan \& Barbosa-Canovas, 1997). An increase in particle size of ground cereals when MC is low decreases the bulk and particle densities of flours (Mani, Tabil \& Sokhansanj, 2004a). The particle size of corn is affected by the production system of the grain, and feed manufacturing process (grain cleaning and grinding equipment) either by using a hammer mill (screen size, tip speed, screen opening, air systems) or roller mill (corrugations, roll differentials, and gap settings) (Stark, 2016; Koch, 1996; Waldroup, 1997). In roller milling, smaller grains may escape grinding (Douglas, Sullivan, Bond, Struwe, Baier \& Robeson, 1990), and particles produced are irregularly shaped (Koch, 1996). The particles produced from a hammer mill are spherical and uniformly shaped (Reece, Lott \& Deaton, 1985).

Producing smaller particle sizes increases the number of particles and surface area per unit volume which increases the accessibility to digestive enzymes (Goodbrand, Tokach \& Nelssen, 2002). Handling and mixing of ingredients also become easy when particle sizes are small (Koch, 1996). Even when different grains are ground using the same mill under similar conditions, the resulting flours will have different particle sizes because it depends on the hardness of the grain samples (Nir \& Ptichi, 2001; Rose, Tucker, Kettlewell \& Collier, 2001; Carre, Muley, Gomez, Ouryt, Lafittee, Guillou \& Signoret, 2005). Grain particle size is more important in mash feeds than when processing pellets or crumbles feeds (Nir, Hillel, Ptichi \& Shefet, 1995; Svihus, Klozstad, Perez, Zimonja, Sahlstorm \& Schuller, 2004a; Peron, Bastianelli, Oury, Gomez \& Carre, 2005). The digestive tract of poultry (gizzard) is influenced by the particle size of the feed during its development (Nir, Shefet \& Aaroni, 1994b; Cumming, 1994).

There is a need to optimize the grinding process and to develop particle size specifications for specific purposes. The grinding should give uniform particle sizes, predictable particle size distribution, and the grinding equipment should produce enough flour to meet the feed or ethanol manufacturing processes. Changing the gap sizes of roller mill equipment and using a grain of yellow dent corn with different MC could impact the physical properties of the resulting flour. For this reason, the objective of this study was to determine the effects that the different moisture contents of the yellow dent corn, and the roller gap sizes have on the physical properties of the resulting corn flours. The possibility to use the resulting flours in the feed manufacturing and ethanol production industries was also considered.

\section{Materials and Methods}

\subsection{Experimental Design}

Flour was prepared from commercial yellow dent corn samples. The corn grains with moisture contents (MC) were adjusted to $8 \%, 14.0 \%$, and $18 \%$. The roller gap sizes (GAP) used were $0.1016 \mathrm{~mm}, 0.2032 \mathrm{~mm}$, and $0.3048 \mathrm{~mm}$. A completely randomized factorial design was used.

\subsection{Milling of Grain}

A Witt Corrugated-Roller Mill was used to fractionate the whole grain into grits using a roller of corrugations of $1 / 8$ inches. The obtained grits were further milled using corrugations of $1 / 32$ inches to produce the flours. The roller mill with corrugations of $1 / 32$ inches, had its GAP adjusted to $0.1016 \mathrm{~mm}, 0.2032 \mathrm{~mm}$, and $0.3048 \mathrm{~mm}$ to obtain different resulting flours.

\subsection{Moisture Contents of Grain and Flour}

The MC of grain was determined in triplicates using samples of $30 \mathrm{~g}$ at $103^{\circ} \mathrm{C}$ for $72 \mathrm{~h}$, following ASAE S352.2 (ASAE, 2001). The flour MC was determined using $2 \mathrm{~g}$ at $130^{\circ} \mathrm{C}$ for $1 \mathrm{~h}$ (AACC International, 2022).

\subsection{Loss in Flour and Particle Sizes of Flour}

The loss in flour was determined as a percentage of the initial mass of the grit obtained from using $1 / 8$ inches 
corrugated roller. It is caused by the technical performance of milling machinery or incompetence operator. In determining the particle sizes of the flour, $100 \mathrm{~g}$ of the flour was passed through stacks of different sieve sizes by using the Tyler Ro-Tap sieve shaker (RX-29). ASAE S319.4 (2008) method was used in this analysis with US Sieve numbers between $10-270$. The amount of flour on each sieve was used to determine the geometric mean diameter $\left(\mathrm{D}_{\mathrm{gw}}\right)$ and the geometric standard deviation $\left(\mathrm{S}_{\mathrm{gw}}\right)$. The calculations were performed according to the equations described in ANSI/ASAE Standard S319.4. $\mathrm{D}_{\mathrm{gw}}$ and $\mathrm{S}_{\mathrm{gw}}$ of flour particles were calculated using following equations;

$$
\begin{gathered}
D_{g w}=\log ^{-1}\left[\frac{\sum_{i=1}^{n}\left(W_{i} \log \bar{d}_{i}\right)}{\sum_{i=1}^{n} W_{i}}\right] \\
S_{g w}=\log ^{-1}\left[\frac{\sum_{i=1}^{n} W_{i}\left(\log \bar{d}_{i}-\log D_{g w}\right)}{\sum_{i=1}^{n} W_{i}}\right]
\end{gathered}
$$

Where $\mathrm{W}_{\mathrm{i}}$ is mass on the $\mathrm{i}^{\text {th }}$ sieve $(\mathrm{g}), \mathrm{d}_{\mathrm{i}}$ is the nominal sieve aperture size of the $\mathrm{i}^{\text {th }}$ sieve $(\mathrm{mm})$.

\subsection{Color of Flour}

A Minolta Chroma Meter was used to measure the colors of the flours, and measurements were taken in triplicate. The color scores of the flours were reported in terms of 3-dimensional color space based on the following rating scale: $\mathrm{L}^{*} 100=$ white, $0=$ black; $\mathrm{a}^{*}+/-=$ red/green; $\mathrm{b}^{*}+/-=$ yellow/blue. The color values of a typical white flour, for example, were $L^{*}$ value +92.5 whiteness, $a^{*}$ value -2.4 green colors, $b^{*}$ value +6.9 yellow color.

\subsection{Analysis of Data}

The data were analyzed using ANOVA to determine if mean values were significantly different, and if so, then Tukey Kramer HSD was used (at 5\%) to identify where the significant differences in means did occur.

\section{Results and Discussion}

\subsection{Effect of the Corn Grain MC and GAP on the Geometric Mean Diameter ( $\left.D_{g w}\right)$ of Flour Particles for Feed Production}

The $\mathrm{D}_{\mathrm{gw}}$ increased with increasing grain MC, but the difference in GAP did not affect the $\mathrm{D}_{\mathrm{gw}}$. The grain with $8 \%$ MC had the smallest $\mathrm{D}_{\mathrm{gw}}(0.59 \mathrm{~mm})$, and the $\mathrm{D}_{\mathrm{gw}}$ was higher for the grain with $14.0 \%$ and $18 \%$ MC (Table 1). The effect of changing GAP on $\mathrm{D}_{\mathrm{gw}}$ was only observed in the interactive effect with the grain MC. In Table 2, the interactive effect shows that irrespective of the GAP, grain with $18 \% \mathrm{MC}$ had the highest $\mathrm{D}_{\mathrm{gw}}$. The grain with $14.0 \% \mathrm{MC}$ had the highest $\mathrm{D}_{\mathrm{gw}}$ when the GAP of $0.2032 \mathrm{~mm}$ and $0.3048 \mathrm{~mm}$ were used. The $\mathrm{D}_{\mathrm{gw}}$ decreased with corresponding decreases in the MC and GAP, for example, $8 \% \mathrm{MC}$ had the lowest $\mathrm{D}_{\mathrm{gw}}$ using $0.1016 \mathrm{~mm}$. The results indicate that $\mathrm{D}_{\mathrm{gw}}$ was dependent on grain MC and GAP. Depending on the preferences of the feed producers, the grain of suitable MC and GAP with recommended $\mathrm{D}_{\mathrm{gw}}$ are to be used.

Table 1. Individual effect of grain MC (moisture content) or roller gap on the $\mathrm{D}_{\mathrm{gw}}$ (geometric mean diameter) of the resulting flour particles

\begin{tabular}{lll}
\hline Grain MC (\% w.b.) & Geometric Mean Diameter, $\mathbf{D}_{\mathbf{g w}}(\mathbf{m m})$ & Geometric Standard Deviation, $\mathbf{S}_{\mathbf{g w}}(\mathbf{m m})$ \\
\hline 8.0 & $0.59 \pm 0.05^{\mathrm{b}}$ & $1.83 \pm 0.04$ \\
14.0 & $0.68 \pm 0.06^{\mathrm{a}}$ & $1.91 \pm 0.04$ \\
18.0 & $0.73 \pm 0.02^{\mathrm{a}}$ & $1.95 \pm 0.04$ \\
Roller gap size (mm) & & \\
0.1016 & $0.63 \pm 0.08^{\mathrm{a}}$ & $1.91 \pm 0.03$ \\
0.2032 & $0.67 \pm 0.08^{\mathrm{a}}$ & $1.91 \pm 0.03$ \\
0.3048 & $0.71 \pm 0.04^{\mathrm{a}}$ & $1.91 \pm 0.03$ \\
\hline
\end{tabular}

Means \pm standard deviations with different superscripts in the same column for MC or GAP are significantly different at $\mathrm{P}<0.05 . \mathrm{MC}$ is $8 \%, 14.0 \%$ and $18 \%$ 
Table 2. Treatment interaction effects of grain MC (moisture content) and roller gap on the $\mathrm{D}_{\mathrm{gw}}$ (geometric mean diameter) and $\mathrm{S}_{\mathrm{gw}}$ (geometric standard deviation) of the resulting flour particles

\begin{tabular}{lllll}
\hline & Grain MC (\% w.b.) & \multicolumn{3}{l}{ Roller gap size $(\mathbf{m m})$} \\
\cline { 3 - 5 } & & $\mathbf{0 . 1 0 1 6}$ & $\mathbf{0 . 2 0 3 2}$ & $\mathbf{0 . 3 0 4 8}$ \\
\hline $\mathbf{D}_{\mathbf{g w}}$ & 8.0 & $0.54 \pm 0.01^{\mathrm{e}}$ & $0.57 \pm 0.01^{\mathrm{de}}$ & $0.66 \pm 0.01^{\mathrm{bc}}$ \\
& 14.0 & $0.62 \pm 0.01^{\mathrm{cd}}$ & $0.71 \pm 0.01^{\mathrm{ab}}$ & $0.73 \pm 0.01^{\mathrm{a}}$ \\
& 18.0 & $0.72 \pm 0.01^{\mathrm{a}}$ & $0.72 \pm 0.01^{\mathrm{a}}$ & $0.75 \pm 0.01^{\mathrm{a}}$ \\
$\mathbf{S}_{\mathbf{g w}}$ & 8.0 & $1.88 \pm 0.02$ & $1.79 \pm 0.00$ & $1.82 \pm 0.00$ \\
& 14.0 & $1.92 \pm 0.01$ & $1.92 \pm 0.01$ & $1.88 \pm 0.01$ \\
& 18.0 & $1.99 \pm 0.01$ & $1.94 \pm 0.01$ & $1.93 \pm 0.01$ \\
\hline
\end{tabular}

Means \pm standard deviations of the interaction with different superscripts are significantly different at $\mathrm{P}<0.05$. $\mathrm{MC}$ is $8 \%, 14.0 .0 \%$ and $18 \%$

The dried corn $(8 \%)$ had a brittle endosperm that made the grinding very smooth than the grain with high MC $(14.0 \%$ and $18 \%)$. The soaked water in the high moisture corn $(14.0 \%$ and $18 \%)$ might have hardened the starch, endosperm, and seed coat which resulted in rough and large-sized particles. It has been reported that hard seeds produce a relatively low percentage of fine particles after grinding (Carre et al., 2005). According to Stark (Stark, 2016), a higher GAP produces large-sized particles. Rose et al. 2001 reported that endosperm hardness influenced the milling outcome of wheat, thus, harder endosperms produced larger, irregularly shaped particles while soft endosperm produced small-sized particles. Since the $8 \%$ moisture corn was dry, the endosperm was brittle and soft, and therefore smoother particles were produced. Comparatively, the endosperms of the $14.0 \%$ and $18 \% \mathrm{MC}$ grain were hard and resilient to break which resulted in large-sized particles.

The advantages of using the $8 \%$ MC grain are observable in the digestive system of livestock and industrial processing of feed which requires small-sized particles. Small-sized particles have the advantage of an increased number of particles and surface area per unit volume, and therefore accessibility to digestive enzymes also increases (Goodbrand et al., 2002). Small-sized particles also make feed formulation processing less complex (Koch, 1996; Mathew, Hoseney \& Faubion, 1999; Carvalho \& Ascheri, 1999). Preparing different types of feeds for livestock (ruminants), swine, and poultry require particular-sized particles. The benefits of particle size reduction are to improve feed digestion, improve binding ability between particles, improve the mixing efficiency of ingredients in a compounded feed, increase particle homogeneity, and prevent ingredient separation (Stark, 2016; Ying \& Allen, 1998; Stark, Jones, Goodband \& Kalivoda, 2010). Using flour prepared from the grain with $14.0 \% \mathrm{MC}$ and the smallest GAP $(0.1016 \mathrm{~mm})$ can be advantageous in the feed industry because the flour had a smaller $\mathrm{D}_{\mathrm{gw}}(0.62 \mathrm{~mm})$. This is because flours with high MC and small-sized particles are reported to have many advantages. Reports indicate that finely ground flour with high MC increased the rate and level of rumen fermentation and digestion (Ying \& Allen, 1998; Lykos \& Varga, 1995; Knowlton, Glenn \& Erdman, 1998), and digestion in swine (Steinhart, Tokach \& DeRouchey, 2012).

However, there should be a limit to particle size used, because small-sized particles could increase the risk of rumen acidosis in cattle, reduce the dry matter intake and rumen fermentation, and milk characteristics (Ying \& Allen, 1998). MC and particle size distribution contribute significantly to the flow and compressibility properties of biomass feedstocks (Fitzpatrick et al., 2004; Yan \& Barbosa-Canovas, 1997). Grain with low MC (8\%) and a smaller GAP $(0.1016 \mathrm{~mm}$ and $0.2032 \mathrm{~mm})$ can increase dust problems, increase feed processing cost, and also increase the incidence of gastric ulcers in swine (Steinhart, Tokach \& DeRouchey, 2012). The digestive tract of poultry (gizzard) is influenced by feed particle size during development (Nir \& Ptichi, 2001; Nir, Shefet \& Aaroni, 1994b; Cumming, 1994). Generally, broilers require diets having relatively large particle sizes. However, small-sized particles are important when preparing feed pellets for poultry (Amerah, Ravindran, Lentle \& Thomas, 2007). Different animals have different feed particle size requirements. Swine's feed efficiency improves using small-sized particles $\left(0.54 \mathrm{~mm}\right.$ and $\left.0.57 \mathrm{~mm} \mathrm{D_{gw }}\right)$, and poultry's feed efficient increases using large-sized particles (0.71-0.75 mm D gw $_{\text {) }}$ (Stark, 2016; Nir \& Ptichi, 2001; Stark et al., 2010; Steinhart, Tokach \& DeRouchey, 2012). Therefore feed producers should be aware of the grain MC and GAP used to obtain appropriate particle size formation.

\subsection{Effect of Grain MC and GAP on Geometric Mean Diameter $\left(D_{g w}\right)$ of Particles of Flour for Ethanol Production}

Another industrial usage of yellow dent corn is in the ethanol production sector. The particle size in ethanol production is important as it directly relates to the amount of starch released. In this study, the $\mathrm{D}_{\mathrm{gw}}$ was in the 
range of $0.54 \mathrm{~mm}$ to $0.75 \mathrm{~mm}$ (Table 1). The grain with $8 \% \mathrm{MC}$ generally had the smallest $\mathrm{D}_{\mathrm{gw}}$ than the grain with higher MC, but the different GAP did not change the $\mathrm{D}_{\mathrm{gw}}$. The effect of GAP was observed only in the interactive effect (Table 2). Lamsal et al. (2011) reported $\mathrm{D}_{\mathrm{gw}}$ in the range of $1.18 \mathrm{~mm}$ and $1.27 \mathrm{~mm}$ using the GAP between $0.2032 \mathrm{~mm}$ and $0.508 \mathrm{~mm}$, and corn grain with $15 \% \mathrm{MC}$. The results of this study differ from that of Lamsal et al. 2011 and could be due to varietal differences in the corn grain used. Rausch et al. 2005 reported in their survey of nine dry-grind ethanol plants in the upper Midwest United States, that $\mathrm{D}_{\mathrm{gw}}$ of ground corn was $0.94 \mathrm{~mm}$. This value was above the $\mathrm{D}_{\mathrm{gw}}$ obtained in our current study. However, a recent study by Liu, 2009 showed the $\mathrm{D}_{\mathrm{gw}}$ of ground corn particles from six dry-grind ethanol plants in Iowa and South Dakota to range from $0.43 \mathrm{~mm}$ to $0.52 \mathrm{~mm}$. Therefore, it would be appropriate to use grain with $8 \%$ MC and GAP $0.1016 \mathrm{~mm}$ and $0.2032 \mathrm{~mm}$ to produce flour of suitable size for ethanol production.

Using grain with $14.0 \%$ and $18 \% \mathrm{MC}$ produced $\mathrm{D}_{\mathrm{gw}}$ above the average size $(0.48 \mathrm{~mm})$ used in most ethanol plants even at the lowest GAP used $(0.1016 \mathrm{~mm})$. Reports have also indicated that small-sized particles increase ethanol productivity (Kelsall \& Lyons, 2003; Naidu, Singh, Johnston, Rausch \& Tumbleson, 2007; Yeh, Huang \& Chen, 2010; Lamsal, Wang \& Johnson, 2011; Khullara, Dien, Rausch, Tumblesona \& Singh, 2013). The finer the flour, the higher the enzyme kinetics and quantity of sugars produced, because of the increased surface area of the small-sized particles available to enzymes (Kelsall \& Lyons, 2003). According to Khullar et al. 2013, using a $0.08 \mathrm{~mm}$ sieve screen produced a high percentage of ethanol conversion than using a $2 \mathrm{~mm}$ and $6 \mathrm{~mm}$. Small-sized particles were reported to cause several problems during the ethanol production including higher power requirements and harder separation process in the decanter and thin stillage evaporator. Considering the short tempering process time, the grain with $8 \% \mathrm{MC}$ was appropriate. Hurburgh et al. 2014 reported grain MC to be theoretically between $8 \%$ and $14.0 \%$. The smallest GAP $(0.1016 \mathrm{~mm})$ can best be selected because the $\mathrm{D}_{\mathrm{gw}}$ obtained using the grain with $8 \%$ MC could have high soluble solid content in the thin stillage of the ethanol fermentation. However, for grain with the same MC, changing GAP may not have any statistically significant effect on $\mathrm{D}_{\mathrm{gw}}$ of the flour (Table 1) and probably ethanol production. This observation supports the findings of Lamsal et al. 2011; different GAP tested for a grain of the same MC did not give any significant difference in the value of the ethanol produced.

\subsection{Effect of Grain MC and GAP on Loss in the Flour, and the Flour MC}

Table 3. Individual effect of grain MC (moisture content) or roller gap on the losses in flour, and resulting flour MC

\begin{tabular}{lll}
\hline Grain MC (\% w.b.) & Loss in flour (\%) & Flour MC (\% w.b.) \\
\hline 8.0 & $2.07 \pm 0.76^{\mathrm{a}}$ & $8.75 \pm 1.607^{\mathrm{b}}$ \\
14.0 .0 & $0.67 \pm 0.27^{\mathrm{b}}$ & $14.0 .33 \pm 1.81^{\mathrm{ab}}$ \\
18.0 & $1.00 \pm 0.80^{\mathrm{b}}$ & $22.0 \pm 10.50^{\mathrm{a}}$
\end{tabular}

\section{Roller gap size (mm)}

$0.1016 \quad 1.37 \pm 0.73 \quad 14.0 .25 \pm 6.01$

$0.2032 \quad 1.10 \pm 1.06 \quad 16.58 \pm 9.84$

Means \pm standard deviations with different superscripts in the same column are significantly different at $\mathrm{P}<0.05$. $\mathrm{MC}$ is $8 \%, 14.0 .0 \%$ and $18 \%$

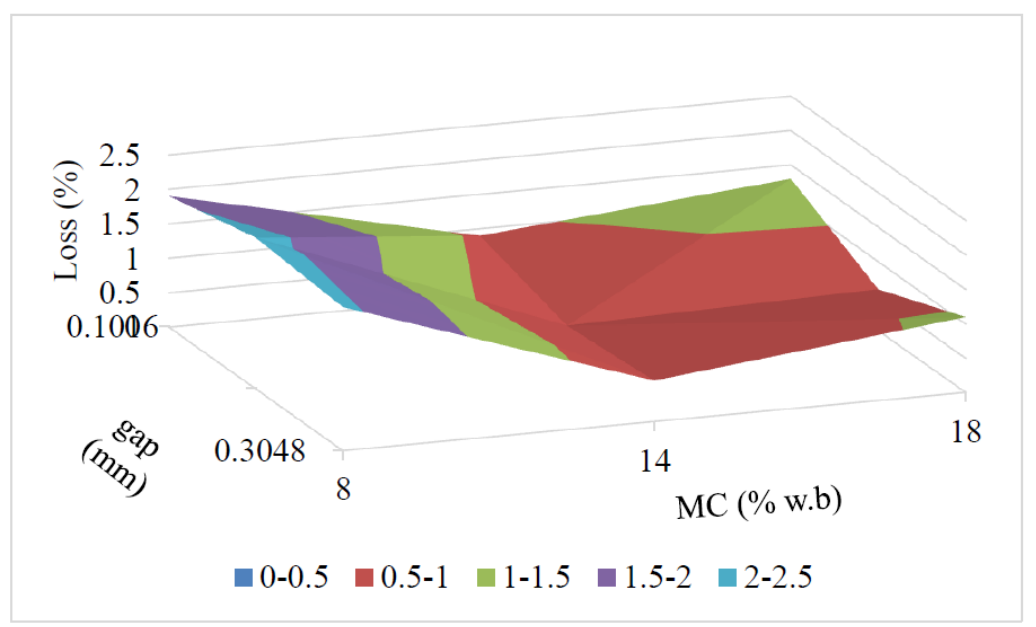

Figure 1. The impact of grain moisture content (\% w.b.) and roller gap $(\mathrm{mm})$ on losses in flour 
In Table 3, the varied GAP did not affect the flour MC and loss in flour quantity, however, grain MC resulted in a loss in quantity of the flour. The quantity of the flour lost significantly depended on grain MC. Due to this, the highest loss was observed in the grain with the lowest MC (8\%) but was minimal in the grain with $14.0 \%$ and $18 \%$ MC. The dried endosperm of grain when ground easily shatters to disperse clouds of smooth powdery flour, and therefore most of the resulting flour is escaped and was counted as a loss. This might have been the reason for the highest flour loss in grain with $8 \% \mathrm{MC}$ compared to moist grain which prevents the shattering and dispersing of the endosperms. This result was illustrated in Figure 1.

The flour MC depended on the grain MC. The grain with the 18\% MC produced flour with a corresponding high MC of 22\%. Although high MC can result in deterioration, but it also could increase cohesion and adhesion of particles by forming interparticle bonds in bulk powdered materials (Plinke et al., 1995; Fitzpatrick et al., 2004), and flowability is decreased (Yan \& Barbosa-Canovas, 1997). Hence, to minimize the loss in flour quantity, the $\mathrm{MC}$ of grain should be less than $8 \%$. Additionally, the high flour MC could cause deterioration and reduces the feed's shelf-life.

\subsection{Effect of Grain MC, GAP, and their Interaction $\left(M C^{*} G A P\right)$ on the Flour Color}

The type and form of animal feed preparation correlate to some flour properties including flour MC, particle size, color, etc. Color is an important factor in feed processing and can make the end product acceptable or unacceptable to the feed buyer. In Table 4, GAP, and grain MC and GAP interaction did not have any effect on the color of the flour $\left(\mathrm{L}^{*}, \mathrm{a}^{*}\right.$, and $\left.\mathrm{b}^{*}\right)$. But grain MC only significantly affected $\mathrm{a}^{*}$ (red) color of the flour. The only significant effect on the color of the flour $\left(\mathrm{a}^{*}\right)$ was the grain with $18 \%$ MC. Thus, $\mathrm{a}^{*}$ (red) color was significantly the same for the flours from the grain with $8 \%$ and $14.0 \% \mathrm{MC}$ (Table 5). The red color of corn lies in the hull (HAES, 1904). As grain absorbs water the red pigment becomes very noticeable. Hence, the flour from the grain with $18 \% \mathrm{MC}$ had the highest red color compared to the flours from the $8 \%$ and $14.0 \% \mathrm{MC}$. Thus, the compound for the red coloration reacted with the high amount of water, making it very noticeable. The result shows that irrespective of the MC and GAP, the flours had similar white ( $\left.\mathrm{L}^{*}\right)$ and yellow (b*) colors. White color is a property that correlates best with processing; however, the increased MC and GAP did not affect the white color of the flour. Since the MC and GAP did not affect the white $\left(\mathrm{L}^{*}\right)$ color this is a better indication for feed or food preparation. Figure $2(a-b)$ illustrates the effect of grain moisture content and roller gap on flour color.

Table 4. Treatment interaction effects of grain MC (moisture content), roller gap, and treatment interaction effects of the $\mathrm{MC}^{*}$ gap interaction on the resulting flour color (p-values)

\begin{tabular}{lllll}
\hline & $\mathbf{L}^{*}$ & $\mathbf{a}^{*}$ & $\mathbf{b}^{*}$ \\
\cline { 2 - 4 } & 0.42 & $0.03^{*}$ & 0.46 \\
Rrain MC & 0.80 & 0.30 & 0.70 \\
Moller gap size (gap) & 0.70 gap interaction & 0.47 & 0.99 & 0.56 \\
\hline
\end{tabular}

*Significant effect at $\mathrm{P}<0.05$. $\mathrm{MC}$ is $8 \%, 14.0 .0 \%$ and $18 \%$

Table 5. Individual effect of grain MC (moisture content) on the resulting flour color

\begin{tabular}{llll}
\hline Grain MC (\% w.b.) & $\mathbf{L}^{*}$ & $\mathbf{a}^{*}$ & $\mathbf{b}^{*}$ \\
\hline 8.0 & $85.85 \pm 6.02$ & $3.49 \pm 0.76^{\mathrm{b}}$ & $30.03 \pm 2.50$ \\
14.0 .0 & $94.75 \pm 11.93$ & $3.91 \pm 0.94^{\mathrm{b}}$ & $33.38 \pm 4.97$ \\
18.0 & $91.62 \pm 12.85$ & $6.00 \pm 1.90^{\mathrm{a}}$ & $30.69 \pm 5.20$ \\
\hline
\end{tabular}

Means \pm standard deviations in the same column with different superscript are significantly different at $\mathrm{P}<0.05$. 


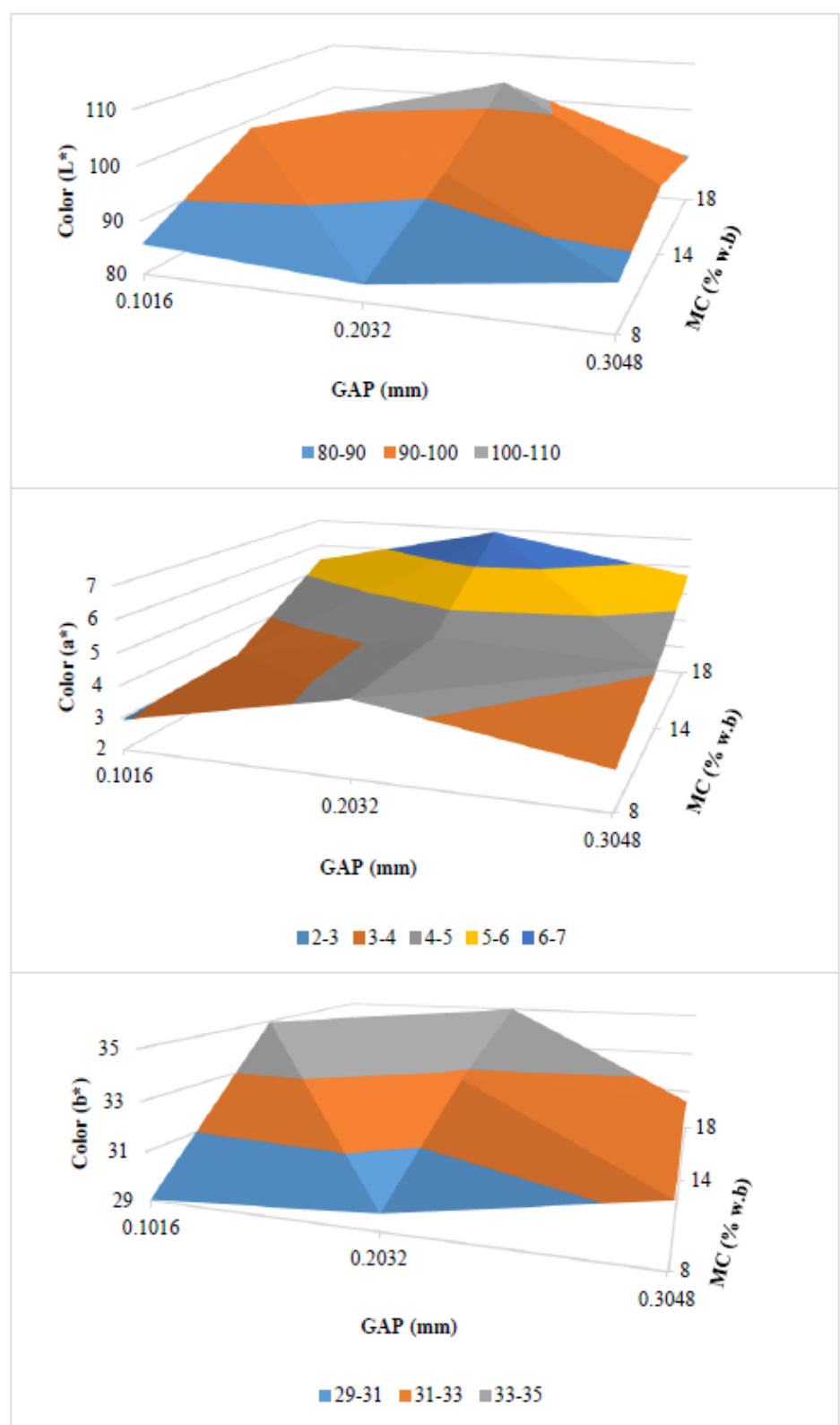

Figure 2 (a) (b) (c). The impact of grain moisture content (\% w.b.) and roller gap size (mm) on flour color ( $\mathrm{L}^{*}$, $\left.a^{*}, b^{*}\right)$.

\section{Conclusions}

The obtained particle sizes ranged from $0.54 \mathrm{~mm}$ to $0.75 \mathrm{~mm}$. There was a corresponding increase in particle sizes as grain MC and GAP increased. In preparing swine feed which generally requires particle size of flour of around $0.5 \mathrm{~mm}$, using grain with $8 \% \mathrm{MC}$ and GAP of $0.1016 \mathrm{~mm}$ and $0.2032 \mathrm{~mm}$ or grain with $14.0 \% \mathrm{MC}$ and $\mathrm{GAP}$ of $0.1016 \mathrm{~mm}$ can produce flour of the required particle size. This is to improve feed efficiency and reduce daily grain intake. In preparing ruminants' feed which generally requires flour particle size of around $0.7 \mathrm{~mm}$, using grain with $8 \% \mathrm{MC}$ and GAP of $0.3048 \mathrm{~mm}$, or grain with $14.0 \% \mathrm{MC}$ and GAP of $0.1016 \mathrm{~mm}$ and 0.2032 $\mathrm{mm}$ can produce flour of the required particle size. Reportedly, this improves milk production, digestion, and reduces gastric ulcers. For poultry feed of particle size which is generally above $0.7 \mathrm{~mm}$, using grain with $18 \%$ $\mathrm{MC}$ and GAP of $0.1016 \mathrm{~mm}$ or grain with $14.0 \% \mathrm{MC}$ and GAP of $0.2032 \mathrm{~mm}$ can produce flour of the required particle size. These particle sizes have been reported to enhance egg production, digestion, and broiler developments. Using GAP of $0.1016 \mathrm{~mm}$ and grain with $8 \% \mathrm{MC}$ can produce flour of particle sizes suitable for the ethanol production industry. The white and yellow colors of the resulting flour were not affected by the different levels of MC and GAP. The effect of the grain MC on the flour color was only significant for the red 
color in the $18 \%$ MC grain. Per the purpose of the flour preparation (feed or ethanol production), the grain MC and GAP can be carefully selected to obtain desirable particle sizes.

\section{Acknowledgments}

We thank the Center for Crops Utilization Research at Iowa State University for providing the roller mill.

\section{References}

AACC International. (2022). Approved Methods of Analysis (11th Ed.). Method 44-15.02. Moisture - Air-Oven Methods. AACC International, St. Paul, MN, U.S.A.

Adarkwah, C., Obeng-Ofori, D., Büttner, C., Reichmuth, C., \& Schöller, M. (2012). Potential of lariophagus distinguendus (Förster) (Hymenoptera: Pteromalidae) to suppress the maize weevil Sitophilus zeamais Motschulsky (Coleoptera: Curculionidae) in bagged and bulk stored maize. Biological Control, 60, 175-181. https://doi.org/10.1016/j.biocontrol.2011.11.003

Amerah, A. M., Ravindran, V., Lentle, R. G., \& Thomas, D. G. (2007). Feed particle size: Implications on the digestion and performance of poultry. World's Poultry Science Journal, 63, 439-445. https://doi.org/10.1017/S0043933907001560

ASAE. (2008). Method of determining and expressing fineness of feed materials by sieving. In American Society of Agricultural Engineers Standard S319.4. Yearbook of Standards, American Society of Agricultural Engineers, St. Joseph, MO.

Bolade, M. K., Adeyemi, I. A., \& Ogunsua, A. O. (2009). Influence of particle size fractions on the physicochemical properties of maize flour and textural characteristics of a maize-based non-fermented food gel. Int. J. Food Sci. Technol., 44, 646-655. https://doi.org/10.1111/j.1365-2621.2008.01903.x

Boutard, A. (2012). Beautiful Corn: America's Original Grain from Seed to Plate. New Society Publishers, Gabriola Island, Canada.

Brown, W., \& Darrah, L. (1985). "Origin, adaptation, and types of corn. Natl," in Corn Handbook. Cooperative Extension Service. Iowa State University, Iowa. NCH-10. pp. 1-6.

Carre, B., Muley, N., Gomez, J., Ouryt, F. X., Lafittee, E., Guillou, D., \& Signoret, C. (2005). Soft wheat instead of hard wheat in pelleted diets results in high starch digestibility in broiler chickens. British Poultry Science, 46, 66-74. https://doi.org/10.1080/00071660400023847

Carvalho, C. W. P., \& Ascheri, J. L. R. (1999). Effect of dry-milling on physicochemical characteristics of white corn extrudates. Alimentaria, 305, 115-119.

Cumming, R. B. (1994). Opportunities for whole-grain feeding. Proceedings of the 9th European Poultry Conference, Vol. 2, World Poultry Science Association, Glasgow, United Kingdom. pp. 219-222.

Douglas, J. H., Sullivan, T. W., Bond, P. L., Struwe, F. J., Baier, J. G., \& Robeson, L. G. (1990). Influence of grinding, rolling, and pelleting on the nutritional value of grain sorghums and yellow corn for broilers. Poultry Science, 69, 2150-2156. https://doi.org/10.3382/ps.0692150

Fitzpatrick, J. J., Iqbal, T., Delaney, C., Twomey, T., \& Keogh, M. K. (2004). Flow property measurement of food powders and sensitivity of Jenike's hopper design methodology to the measured values. J. Food Eng., 61, 399-405. https://doi.org/10.1016/S0260-8774(03)00147-X

Goodbrand, R. D., Tokach, M. D., \& Nelssen, J. L. (2002). The effects of diet particle size on animal performance. MF-2050 Feed Manufacturing. Department of Grain Science and Industry, Kansas State University. pp. 6.

HAES. (1904). Hawaii Agricultural Experiment Station. In Press Bulletin, 9-54(1904-1919), 3.

Hardacre, A. K., \& Clark, S. M. (2006). The effect of hybrid and growing environment on the rheological properties of starch and flour from maize (Zea mays L.) grain dried at four temperatures. Int. J. Food Technol., 41, 14.04-150. https://doi.org/10.1111/j.1365-2621.2006.01471.x

Hurburgh, C. R., Bern, C. J., \& Brumm, T. J. (2014). Grain moisture and weight. In Managing grain after harvest. In Agricultural and Biosystem Engineering Department, Iowa State University, Chapter 2.

Johnson, L. A. (1991). Corn: production, processing, and utilization. In K. J. Lorenz, \& K. Kulp (Eds.), Handbook of Cereal Science and Technology (pp. 55-131). Marcel Dekker, New York.

Kelsall, D. R., \& Lyons, T. P. (2003). Grain dry milling and cooling procedures: Extracting sugars in preparation 
for fermentation. In K. A. Jacques, T. P. Lyons, \& D. R. Kelsall (Eds.), The Alcohol Textbook: A Reference for the Beverage, Fuel and Industrial Alcohol Industries (pp. 9-21). Nottingham University Press, Nottingham, UK.

Khullara, E., Dien, B. S., Rausch, K. D., Tumblesona, M. E., \& Singh, V. (2013). Effect of particle size on enzymatic hydrolysis of pretreated Miscanthus. Industrial Crops and Products, 44, 11-17.

https://doi.org/10.1016/j.indcrop.2012.10.015

Knowlton, K. F., Glenn, B. P., \& Erdman, R. A. (1998). Performance, ruminal fermentation, and site of starch digestion in early lactation cows fed corn grain harvested and processed differently. J. Dairy Sci., 81, 1972-1984. https://doi.org/10.3168/jds.S0022-0302(98)75771-6

Koch, K. (1996). Hammermills and roller mills, "MF-2048 Feed Manufacturing”. Department of Grain Science and Industry, Kansas State University. pp. 8.

Lamsal, B. P., Wang, H., \& Johnson, L. A. (2011). Effect of corn preparation methods on dry-grind ethanol production by granular starch hydrolysis and partitioning of spent beer solids. Bioresource Technology, 102, 6680-6686. https://doi.org/10.1016/j.biortech.2011.03.040

Liu, K. S. (2009). Effects of particle size distribution, compositional and color properties of ground corn on quality of distillers dried grains with solubles (DDGS). Bioresour. Technol., 100, 4433-4440. https://doi.org/10.1016/j.biortech.2009.02.067

Lykos, T., \& Varga, G. A. (1995). Effects of processing method on degradation characteristics of protein and carbohydrate sources in situ. J. Dairy Sci., 78, 1789-1801. https://doi.org/10.3168/jds.S0022-0302(95)76804-7

Mani, S., Tabil, L. G., \& Sokhansanj, S. (2004a). Mechanical properties of corn stover grind. Trans. ASAE, 47, 1983-1990. https://doi.org/10.13031/2013.17786

Martinez-Flores, H. E., Martinez, B. F., Figueroa, C. J. D., \& Gonza-lez, H. J. (1998). Tortillas from extruded masa as related to corn genotype and milling process. Journal of Food Science, 63, 130-133. https://doi.org/10.1111/j.1365-2621.1998.tb15692.x

Mathew, J. M., Hoseney, R. C., \& Faubion, J. M. (1999). Effects of corn sample, mill type, and particle size on corn curl and pet food extrudates. Cereal Chemistry, 76, 621-624.

https://doi.org/10.1094/CCHEM.1999.76.5.621

Nago, M., Akiossoe, N., Matencio, F., \& Mestres, C. (1997). End-use quality of some African corn kernels. 1. Physicochemical characteristics of kernels and their relationship with the quality of 'lifin', a traditional whole dry-milled maize flour from Benin. J. Agric. Food Chem., 45, 555-564. https://doi.org/10.1021/jf9507957

Naidu, K., Singh, V., Johnston, D. B., Rausch, K. D., \& Tumbleson, M. E. (2007). Effects of ground corn particle size on ethanol yield and thin stillage soluble solids. Cereal Chem., 84, 6-9. https://doi.org/10.1094/CCHEM-84-1-0006

Nghi, T. T., \& Narasimha, H. V. (1994). Performance of a plate mill and a modified Engelberg huller for small-scale dry milling and degerming of maize. Int. J. Food Sci. Technol., 29, 347-353. https://doi.org/10.1111/j.1365-2621.1994.tb02076.x

Nir, I., \& Ptichi, I. (2001). Feed particle size and hardness: Influence on performance, nutritional, behavioral and metabolic aspects. In Proceedings of the 1st World Feed Conference, Utrecht, the Netherlands. pp. $157-186$.

Nir, I., Hillel, R., Ptichi, I., \& Shefet, G. (1995). Effect of particle size on performance .3. Grinding pelleting interactions. Poultry Science, 74, 771-783. https://doi.org/10.3382/ps.0740771

Nir, I., Shefet, G., \& Aaroni, Y. (1994b). Effect of particle size on performance. Corn Poultry Science, 73, 45-49. https://doi.org/10.3382/ps.0730045

Pan, Z., Eckhoff, S. R., Paulsen, M. R., \& Litchfield, J. B. (1996). Physical properties and dry-milling characteristics of six selected high-oil maize hybrids. Cereal Chem., 73, 517-520.

PE/AI (Plants of Economic or Aesthetic Importance). (2016). Major cereal: maize. Retrieved from http://www.faculty.ucr.edu/ legneref/botany/majcerea.htm

Peron, A., Bastianelli, D., Oury, F. X., Gomez, J., \& Carre, B. (2005). Effects of food deprivation and particle 
size of ground wheat on digestibility of food components in broilers fed on a pelleted diet. British Poultry Science, 46, 223-230. https://doi.org/10.1080/00071660500066142

Plinke, M. A. E., Leith, D., Boundy, M., \& Loffler, F. (1995). Dust generation from handling powders in the industry. American Ind. Hyg. Assoc. J., 56, 251-257. https://doi.org/10.1080/15428119591017088

Rausch, K. D., Belyea, R. L., Ellersieck, M. R., Singh, V., Johnston, D. B., \& Tumbleson, M. E. (2005). Particle size distributions of ground corn and DDGS from dry grind processing. Trans. ASABE, 48, 273-277. https://doi.org/10.13031/2013.17928

Reece, F. N., Lott, B. D., \& Deaton, J. W. (1985). The effects of feed form, grinding method, energy level, and gender on broiler performance in a moderate $\left(21^{\circ} \mathrm{C}\right)$ environment. Poultry Science, 64, 1834-1839. https://doi.org/10.3382/ps.0641834

Rose, S. P., Tucker, L. A., Kettlewell, P. S., \& Collier, J. D. A. (2001). Rapid tests of wheat nutritive value for growing chickens. Journal of Cereal Science, 34, 181-190. https://doi.org/10.1006/jcrs.2001.0390

Sandhu, K. S., Singh, N., \& Malhi, N. S. (2007). Some properties of corn grains and their flours I: Physicochemical, functional and chapati-making properties of flours. Food Chem., 101, 938-946. https://doi.org/10.1016/j.foodchem.2006.02.040

Stark, C. (2016). Factors that Influence Corn Particle Size and its Impact on Pellet Quality. Feed Science Program in the Department of Poultry Science. North Carolina State University, Academics Research Extension. pp. 1-60. Retrieved from https://projects.ncsu.edu/.../feedmill/.../CFIA\%20Corn\%20Symp\%20Particle\%20Size

Stark, C., Jones, C., Goodband, R., \& Kalivoda, J. (2010). Effect of sieving methodology on determining particle size of ground corn, sorghum, and wheat by sieving. Kansas State University-Grain Science and Industry Department.

Steinhart, T. L., Tokach, M. D., \& DeRouchey, J. M. (2012). Swine Feed Efficiency: Influence of Particle Size. The U.S. Department of Agriculture (USDA), IPIC 25d.

Svihus, B., Klozstad, K. H., Perez, V., Zimonja, O., Sahlstorm, S., \& Schuller, R. B. (2004a). Physical and nutritional effects of pelleting of broiler chicken diets made from wheat ground to different coarsenesses by the use of roller mill and hammer mill. Animal Feed Science and Technology, 117, 281-293. https://doi.org/10.1016/j.anifeedsci.2004.08.009

Waldroup, P. W. (1997). Particle Size Reduction of Cereal Grains and its Significance in Poultry Nutrition. Technical Bulletin PO34-1997. American Soybean Association, Singapore. pp. 14.

Yan, H., \& Barbosa-Canovas, G. V. (1997). Compression characteristics of agglomerated food powders: Effect of agglomerate size and water activity. Food Sci. Tech. Intl., 3, 351-359. https://doi.org/10.1177/108201329700300506

Yeh, A. I., Huang, Y. C., \& Chen, S. H. (2010). Effect of particle size on the rate of enzymatic hydrolysis of cellulose. Carbohyd. Polym., 79, 192-199. https://doi.org/10.1016/j.carbpol.2009.07.049

Ying, Y., \& Allen, M. S. (1998). Effects of fineness of grinding and conservation method of corn grain on ruminal starch digestion kinetics in Holstein heifers before and after calving. J. Dairy. Sci., 83, 554-568.

\section{Copyrights}

Copyright for this article is retained by the author(s), with first publication rights granted to the journal.

This is an open-access article distributed under the terms and conditions of the Creative Commons Attribution license (http://creativecommons.org/licenses/by/4.0/). 